\title{
Prevalence and predictors of work-related musculoskeletal disorders among workers of a gold mine in south Kivu, Democratic Republic of Congo
}

\author{
Alfred Okello ${ }^{1}$, Solomon Tsebeni Wafula ${ }^{2^{*}}$ (D), Deogratias K. Sekimpi ${ }^{2}$ and Richard K. Mugambe ${ }^{2}$
}

\begin{abstract}
Background: Work-related musculoskeletal disorders (WRMSDs) are a major constraint to worker performance and health. However, research on their prevalence and associated factors among workers at gold mines in the Democratic Republic of Congo (DRC) is insufficient. The present study aimed to determine the prevalence and predictors of WRMSDs among workers of a Gold Mine in South Kivu, DRC.

Methods: Cross sectional data on prevalence of WRMSDs and risk factors was collected using a modified Nordic questionnaire and upper limb Core QX checklist from 196 workers of a gold mine. WRMSDs were defined as pain or injury(ies) or discomfort, numbness or limitation of movement in the musculoskeletal system at any time in the past 12 months which lasted at least $24 \mathrm{~h}$. These had to be either induced or aggravated by work and circumstances of its performance. A generalised linear model of the Poison family with link log and robust error variances was used to generate prevalence ratios (PRs) and 95\% confidence intervals (Cls) for the factors associated with WRMSDs. The effect of individual, ergonomic and psychosocial factors on WRMSDs were investigated while controlling for known confounders.
\end{abstract}

Results: Most workers were males 187 (95.4\%) and their age ranged between 23 and 60 years with mean of 36.3 years. Of the 196 workers, 49 (25.0\%) reported having at least one WRMSD during the previous 12 months. WRMSDs with highest occurrence rate were the lower back pain (14.8\%), followed by thighs/hip pain (9.2\%) and shoulder pain (8.2\%). Prolonged heavy lifting/shovelling shovelling $(P R=1.69,95 \% \mathrm{Cl}[1.32,3.24]$ and longer work shifts (> 9 h) $(P R=3.56,95 \% \mathrm{Cl}[1.76,16.58])$ were predictive for WRMSDs while jobs with low demands were protective against WRMSDs $(P R=0.18,95 \% \mathrm{Cl}[0.08,0.44])$.

Conclusion: The prevalence of WRMSDs is high and associated with prolonged heavy lifting/shovelling, longer work shifts and job demands. We recommend lowering workload and job demands and improving work ergonomics to mitigate and prevent the WRMSDs among workers in goldmines.

Keywords: Work-related musculoskeletal disorders, Ergonomics, Mining workers, DR Congo

\footnotetext{
* Correspondence: swafula@musph.ac.ug

${ }^{2}$ Department of Disease Control and Environmental Health, Makerere University School of Public Health, Kampala, Uganda

Full list of author information is available at the end of the article
}

(c) The Author(s). 2020 Open Access This article is licensed under a Creative Commons Attribution 4.0 International License, which permits use, sharing, adaptation, distribution and reproduction in any medium or format, as long as you give appropriate credit to the original author(s) and the source, provide a link to the Creative Commons licence, and indicate if changes were made. The images or other third party material in this article are included in the article's Creative Commons licence, unless indicated otherwise in a credit line to the material. If material is not included in the article's Creative Commons licence and your intended use is not permitted by statutory regulation or exceeds the permitted use, you will need to obtain permission directly from the copyright holder. To view a copy of this licence, visit http://creativecommons.org/licenses/by/4.0/. The Creative Commons Public Domain Dedication waiver (http://creativecommons.org/publicdomain/zero/1.0/) applies to the data made available in this article, unless otherwise stated in a credit line to the data. 


\section{Background}

Musculoskeletal disorders (MSDs) have over the years become major health conditions worldwide resulting in increased burden on general medical care. MSDs affect all parts of the body with the back, neck and shoulders and upper limbs accounting for more than $50 \%$ of cases [1-3]. They have negative impacts on quality of life such as workrelated disability as well as substantial financial implications related to medical expenses and workers' compensation [4]. In gold mining, the working conditions are physically demanding and dangerous due to heavy and awkward loads, unstable underground structures, heavy tools and equipment, among other factors often leading to MSDs [5-7].

Work-related musculoskeletal disorders (WRMSDs) resulting from occupational activities present a bigger problem than usually estimated $[8,9]$. WRMSDs are the most expensive occupational conditions and they are the leading work-related health concern, in high income as well as low and middle income countries, accounting for over $30 \%$ of all injuries and requiring time away from work [10]. WRMSDs are highly prevalent in many African countries with the prevalence of any MSD ranging from 15 to $93.6 \%$ [11, 12]. About $20 \%$ of the overall prevalence is contributed by the industrial sector which includes mining [12]. Studies conducted amongst workers of gold mines in South Africa and Ghana found the prevalence of MSDs to be 65.3 and $85 \%$ respectively $[7,10]$. The prevalence of MSDs usually varies between studies due to lack of standard/uniform definitions of MSDs, leading to variations in case definitions and data collecting procedures across studies. The differences in studied populations e.g., by economic activity, further demonstrates the disparities [1, 2, 12, 13]. The Occupational Safety and Health Administration has estimated that WRMSDs are understated by at least a factor of two based on studies and experience [10] .

The etiology and pathogenesis of WRMSDs are complicated and multifactorial. Several factors have been extensively investigated in different occupations [8]. The risk factors of MSDs can be biomechanical, psychosocial, or individual [14]. These risk factors vary over time and in different occupational situations and usually interact with each other to create an elevated risk [7, 8, 15]. The mining workplace may have risk factors related to equipment/vehicle design; work organization (consisting of high job demands; time pressures; lack of job rotation and long working hours without opportunity for rest and recovery); limited access (usually in form of limited working space); duration of task; overtime; and maintenance/breakdowns of equipment $[2,7,10]$.

Despite the startling global figures on WRMSDs, only a few research studies have been conducted in subSaharan Africa, much less in Democratic Republic of Congo (DRC) where mining, a hazardous activity, provides many of its citizens with jobs. This study, therefore, aimed to determine the prevalence of and predictors of WRMSDs amongst workers of Twangiza Mining site in south Kivu, DR Congo.

\section{Methods \\ Study design}

This was a cross-sectional study, conducted among workers in Twangiza Gold Mine, a subsidiary of Banro Corporation in the DR Congo in 2018. In 2011, Twangiza became the first commercial gold mine built in the DRC in over 50 years. It is an open pit gold mine which started commercial gold production in late 2012. It is located $35 \mathrm{~km}$ west of the Burundi border and $45 \mathrm{~km}$ to the southeast of Bukavu in South Kivu.

\section{Study population and sample size}

The study was conducted amongst workers of Twangiza gold mine for 4 weeks from 1st June 2018 to 30th June 2018. Eligibility for participants is shown in Table 1 .

The gold mine employed 691 workers at the time. Workers were stratified into six departments (strata) with each performing different tasks. The different strata were defined by grouping jobs together based on similar job demands. These departments include the mining department (133 members) which does extraction and blasting of gold ore requiring high efforts, engineering (82 members) and maintenance departments (137 members) which are involved in construction and maintenance of equipment respectively thus demanding high impact efforts. Mineral resources (MRM) department (86 members) explores the ore reserves including drilling requiring high efforts. Metallurgy department (116 members) refines and processes gold ore into pure gold with moderate effort requirements. The "others" (137 members) are involved in the transportation of goods/ personnel to and from the mining sites, planning, educating and maintaining health and safety for the company with minimal effort requirements.

The Kish Leslie formula (1965) was used to determine the sample size [16]. We assumed an alpha of 0.05 , power (1beta) of 0.80 , a sampling error of $5 \%$, and prevalence $(\mathrm{P})$ of WRMSDs of $42.6 \%$ was considered from a similar study in Malawi [2]. The sample size was 376 but since the proportion of sample to population was larger than $5 \%$, we then used a finite population correction formula by Daniel [17] with an additional 10\% to account for refusal to participate/ non-response giving an adjusted sample size of $273[18,19]$.

To make the sample size, we set out to randomly select 46 participants from each of the 6 departments (strata). Random sampling was applied instead of proportionate sampling since the departments had similar number of workers. We used a table of random numbers to select the participants per department. Complete data were obtained 
Table 1 Eligibility criteria for recruiting participants in the Musculoskeletal disorders study in Twangiza Gold Mine

\begin{tabular}{ll}
\hline Inclusion criteria & Exclusion criteria \\
\hline - Age of 18 and above & $\begin{array}{c}\text { Child miners below 18years of age. } \\
\text { - Minimum of one year experience at the mining site. }\end{array}$ \\
$\begin{array}{l}\text { - No history of trauma or injuries and psychological problems (information trauma or ongoing psychological problem (information } \\
\text { obtained from annual medical reports at the mine's medical office) }\end{array}$ & $\begin{array}{c}\text { obtained from annual medical reports at the mine's medical office) } \\
\text { - Refusal to consent to participate. }\end{array}$ \\
\hline
\end{tabular}

from 196 gold mining workers hence a response rate of $71.8 \%$. The reasons for non-response include incomplete data, difficulties to schedule appointments since some workers had left for their regular day offs/leave while others had changed their minds not to participate.

\section{Data collection and measurements}

A self-administered questionnaire was developed from existing surveys of musculoskeletal disorders and risk factors. Various questionnaires guided the design of the questionnaire for this study including the standardized Nordic, and the modified versions of the Washington state risk factor checklist and the upper limb Core QX checklist used by Kunda et al., [2, 20]. The Nordic questionnaire is a widely accepted, easy to administer, and cost efficient tool for collecting data on self-reported musculoskeletal discomfort and sickness absence and it has been shown to have high validity for capturing MSDs in various settings [20] and for different body regions [21, 22].

The questionnaire had four sections with the first section providing data on background variables such as age, sex, educational level. The second part consisted of questions on the MSD injury/complaints profile.

The modified version of the Nordic questionnaire measured the subjective ache/pain/numbness/injury on the different body parts. Work related MSD was defined as developing an ache/pain/numbness/injury after starting work at mines or either aggravated by working conditions while on duty (work related) during the last 12 months. A "yes" response to complaints from duty was used to ascertain the prevalence of WRMSDs. The affected body parts (Neck, shoulder, elbows, wrists/hands, upper back, lower back, hips/thighs, knee, ankles/feet) were also recorded under this section.

Section three consisted of the risk factors such as the work-environment characteristics and work-practices such as machines used, postures adopted at work and total work duration per day. The workers reported on health hazards at their job types to provide estimates of safety hazards about risk factors. The workers indicated the length of exposure to an activity which determined the exposure level as being lower risk /cautionary (occasionally/ less than $2 \mathrm{~h}$ per day or less than 10 times per day) or higher risk / hazardous ( $\geq 2 \mathrm{~h} /$ day or $\geq 10$ times/day).

The fourth section recorded the psychological and psychosocial risk factors which were measured using a modified version of the upper limb Core QX checklist [2]. Five questions were asked on job demand and they had responses with the format 1 = strongly disagree; 2 = disagree; 3 =agree; and 4=strongly agree), These responses were collapsed into two categories (agree or disagree) during analysis. Agreement that some aspects of the job are demanding was considered "high job demand" or otherwise low job demand. Job security was considered present if the participant felt he/she is indispensable and less likely to lose their job, otherwise considered job insecure.

We also asked four questions on job control (variety amount, pace and duration of tasks) with responses "very little", "little", moderate", "much" and "very much". These were each collapsed into "little" and "much". A participant was considered to have job control if they indicated much control on any of the four aspects, otherwise considered to have low job control.

Regarding work manship, four questions were asked about receiving support from supervisors with options "Very much", much or (easy)", "little" or "Not at all". These were collapsed to two categories; "little" or "much". Workmanship was then categorised as "good" if workers received much support from supervisors on any of the four aspects or bad if otherwise.

Mental state was evaluated using five questions on anxiety and depression with options rarely or none (Coded 1), sometimes (coded 2), Often (coded3), Most or all of the time (coded4). These were collapsed to two categorises (rarely/ none/sometimes and Often/most or all of the time). Mental state was considered "normal" if the participants indicated none/rarely or sometimes on any of the questions and otherwise considered not normal. The full English questionnaire for the study is provided as supplementary file 1 .

Four individuals were trained as research assistants for 3 days on study aims, procedures, ethics, MSDs, associated factors of MSDs and preventive measures. They distributed and collected the questionnaires and assisted the workers with difficulties encountered during the filling of questionnaires. The research assistants were introduced to the participants and an appointment was made with the mine sectional supervisors and all the participants who were available on the day and time of questionnaire distribution. The questionnaires were distributed by the researcher or research assistants and by the sectional supervisors who were on duty. Those on the night shift had the questionnaires distributed to them by the sectional heads operating at night who had received a briefing from the daytime sectional heads. 
The questionnaires were completed over a 4 weeks period with the researcher and research assistants collecting the completed questionnaires daily and also reminding those who had not yet completed to do so if possible. The original questionnaire was designed in English and later translated into French since most of the workers spoke French and the minority English.

\section{Statistical analysis}

All generated data were entered into a Microsoft Excel database, cleaned and exported to Stata version 14.0 (StataCorp, Texas). Continuous data were expressed as mean and standard deviation. Categorical data variables such as sex, age groups, the prevalence of WRMSDs, prevalence of WRMS Ds by age categories, working (shift) hours, body parts affected, department, exposure to the ergonomic and psychosocial factors were expressed as frequencies and proportions. Prevalence ratios (PRs) were computed using a multivariable modified Poisson regression with the logarithm as the link function, with robust error variances to measure the association between the WRMSDs and independent variables.
Simple models consisting of the outcome and one independent variable were run to obtain the crude PRs. Variables that had $p$ values under liberal threshold of 0.1 in bivariate models were included in the multivariable model [23]. Backward stepwise elimination method was applied until only variables with $p$ value $\leq 0.05$ and those significantly improved the fit of the model were retained. The goodness of fit test showed an insignificant $p$-value of 0.7553 suggesting that the model fitted the data reasonably well. The adjusted PRs and their $95 \%$ confidence intervals are presented.

\section{Results}

Demographic characteristics

The respondents were aged between 23 and 60 years old ( mean $=36.3 ; \mathrm{SD}=7.9$ years). The work experience of the respondents ranged from 1 to 11 years (mean $=4.1$; $\mathrm{SD}=$ 2.0 years) with $72.5 \%$ (142) of the respondents having an experience of 1-5 years. A work shift ranged from 7 to 15 $\mathrm{h}($ mean $=11.2$; $\mathrm{SD}=1.41)$. Majority $83.2 \%$ (163) of the respondents had work shifts of more than $9 \mathrm{~h}$ (Table 2).

Table 2 Demographic characteristics of participants $(N=196)$

\begin{tabular}{|c|c|c|c|}
\hline Characteristic & Category & $n$ & Summary measure \\
\hline \multirow[t]{5}{*}{ Age in years } & $<30$ & 37 & $18.9 \%$ \\
\hline & $30-34$ & 54 & $27.6 \%$ \\
\hline & $35-39$ & 48 & $24.5 \%$ \\
\hline & $\geq 40$ & 57 & $29.1 \%$ \\
\hline & Mean (SD) & & $36.3(7.9)$ \\
\hline \multirow[t]{2}{*}{ Sex } & Males & 187 & $95.4 \%$ \\
\hline & Females & 9 & $4.6 \%$ \\
\hline \multirow[t]{6}{*}{ Department } & Engineering & 32 & $16.3 \%$ \\
\hline & Maintenance & 34 & $17.4 \%$ \\
\hline & Metallurgy & 34 & $17.4 \%$ \\
\hline & Mining & 30 & $15.3 \%$ \\
\hline & Mineral Resources Management & 33 & $16.8 \%$ \\
\hline & Others & 33 & $16.8 \%$ \\
\hline \multirow[t]{3}{*}{ Education level } & Primary & 17 & $8.8 \%$ \\
\hline & Secondary & 83 & $42.8 \%$ \\
\hline & Tertiary & 94 & $48.5 \%$ \\
\hline \multirow[t]{3}{*}{ Working experience (years) } & $1-5$ & 142 & $72.4 \%$ \\
\hline & $>5$ & 54 & $27.6 \%$ \\
\hline & Mean (SD) & & $4.1(2.0)$ \\
\hline \multirow[t]{3}{*}{ Work shifts in hours } & $\leq 9 h$ & 33 & $16.8 \%$ \\
\hline & $>9 h$ & 163 & $83.2 \%$ \\
\hline & Mean (SD) & & $11.2(1.4)$ \\
\hline \multirow[t]{3}{*}{ Reported MSDs occurring in last 12 months } & Reported MSD symptom & 120 & $61.2 \%$ \\
\hline & Did not report any MSD & 76 & $38.8 \%$ \\
\hline & Reported as work-related MSD & 49 & $25.0 \%$ \\
\hline
\end{tabular}




\section{Prevalence of MSDs and WRMSDs}

Of the respondents, $61.2 \%$ (120) reported having had a complaint (pain or discomfort) in some part (s) of their body within 12 months prior to the study. A quarter of the respondents $25.0 \%$ (49) reported that the complaints were work related. Table 3 shows that the 12-months prevalence rates of WRMSDs was highest in the lower back (LBP) $14.8 \%$, followed by hips/thighs $9.2 \%$ and then shoulder $8.2 \%$ (Table 3 ).

\section{Predictors of work-related musculoskeletal disorders}

In multivariable regression, after controlling for age of workers, no significant association was observed between individual factors and reporting WRMSDs (Table 4).

Regarding ergonomic risk factors, workers with a work shift lasting more than $9 \mathrm{~h}$ were 3.56 times more likely to report a WRMSD complaint than those working less than $9 \mathrm{~h}$ a day $(P R=3.56,95 \%$ CI $[1.76,16.58])$. The ergonomic factor significantly associated with reporting a WRMSD was heavy lifting and/or lowering objects. Workers involved in heavy lifting and/or lowering/shovelling for $\geq 10$ times $/ 2 \mathrm{~h}$ per day were 1.69 times more likely to report a WRMSD than those not involved in lifting/lowering/shovelling $(P R=1.69, \quad 95 \%$ CI $[1.32$, 3.24]) (Table 5). Psychosocially, we found that low demanding jobs were protective with the workers being $82 \%$ less likely to report a WRMSD complaint than those with high job demands $(P R=0.18,95 \%$ CI $[0.08$, 0.44]) (Table 6).

\section{Discussion}

With regards to the prevalence of MSDs, about $61.2 \%$ of workers had experienced MSD symptoms in at least one body region and $25.0 \%$ were work-related (WRMSDs). The prevalence of WRMSDs obtained in this study was similar to what has been previously reported among workers in the industrial sector which includes mining in Africa [12]. However, the reported prevalence of WRMS Ds was lower compared to a similar study amongst workers in gold mines in Ghana (85.5\%) [24] and among quarry workers in Southeast Nigeria (83.3\%) [25]. The discrepancy could be explained by the possibility that Twangiza mining site might be better designed ergonomically. We also believe this could be an issue of under reporting by workers who may consider some complaints as nonsignificant. Since we involved supervisors in questionnaire distribution, it is also a possibility that some workers may have underreported MSD complaints for fear of reprisal or due to the thought that the survey could identify those with MSDs as not fit for work.

The body parts susceptible to WRMSDs in our study did not differ from those reported in other studies which reported lower back, shoulders and hands as body regions commonly involved in WRMSDs [26]. The lower back was the most affected body part in this study and it is supported by previous studies which highlight lowback pain as the most frequent WRMSD complaint in any industry [1, 2, 12, 24, 27-29]. Hip complaints were the second most recorded parts contrary to the other studies which reported the wrists/hands [2, 24]. Nevertheless, working in restricted postures such as performing a lift while lying on the ground may incur additional burdens on muscles of the hips and thighs hence higher complaints. Additionally, these workers may have limited knowledge about the work activity hence no effective mitigation measures, an area of research which needs further investigation in future studies.

A significant association was observed between working for $>9 \mathrm{~h}$ and reporting a WRMSD. This confirms earlier studies in different settings that indicated an association between long working time and complaints of WRMSDs [30, 31]. Increase in working hours per day also means increased exposure time to the physical demands during work. Longer work hours are indicators of high workload and have been identified to increase the risk of lower back pain and other WRMSDs [32]. Based on this, we suggest the need to design appropriate system level approaches to reduce exposure/work time for mining workers especially those in most demanding operations.

Table 3 The reported body parts affected by musculoskeletal disorders

\begin{tabular}{lll}
\hline Reported complaint $^{\mathbf{a}}$ & All MSD complaints, $\boldsymbol{n}$ (\%) & Work-related complaints, $\boldsymbol{n}$ (\%) \\
\hline Lower back & $79(40.3)$ & $29(14.8)$ \\
Hips/thighs & $43(21.9)$ & $18(9.2)$ \\
Shoulder & $23(11.7)$ & $16(8.2)$ \\
Wrists/Hands & $25(12.7)$ & $14(7.1)$ \\
Upper back & $33(16.8)$ & $12(6.1)$ \\
Feet & $37(18.9)$ & $12(6.1)$ \\
Knees & $16(8.2)$ & $9(4.6)$ \\
Neck & $18(9.2)$ & $8(4.1)$ \\
\hline
\end{tabular}

MSD musculoskeletal disorder, LBP low back pain

${ }^{\text {a }}$ Multiple responses 
Table 4 Multivariable analysis of the individual predictors of work-related musculoskeletal disorders

\begin{tabular}{|c|c|c|c|c|c|c|}
\hline \multirow[t]{2}{*}{ Individual factors } & \multicolumn{2}{|c|}{ Self-reported WRMSDs in the past 12 months (\%) } & \multicolumn{2}{|c|}{ Unadjusted Model } & \multicolumn{2}{|c|}{ Adjusted model } \\
\hline & Yes $(n=49)$ & No $(n=147)$ & $P R$ & {$[95 \% \mathrm{Cl}]$} & $P R$ & {$[95 \% \mathrm{Cl}]$} \\
\hline \multicolumn{7}{|l|}{ Age in years } \\
\hline$<30$ & $9(24.3)$ & $28(75.7)$ & 1 & & 1 & \\
\hline $30-34$ & $12(22.2)$ & $42(77.8)$ & 0.91 & {$[0.43,1.95]$} & 0.95 & {$[0.47,1.91]$} \\
\hline $35-39$ & $8(16.7)$ & $40(83.3)$ & 0.69 & {$[0.29,1.61]$} & 0.75 & {$[0.33,1.68]$} \\
\hline$\geq 40$ & $20(35.1)$ & $37(64.9)$ & 1.44 & {$[0.74,2.82]$} & 1.63 & {$[0.86,3.09]$} \\
\hline \multicolumn{7}{|l|}{ Department } \\
\hline Mining & $13(43.3)$ & $17(56.7)$ & 1 & & & \\
\hline Engineering & $12(37.5)$ & $20(62.5)$ & 0.87 & {$[0.47,1.59]$} & & \\
\hline Maintenance & $3(8.8)$ & $31(91.2)$ & 0.20 & {$[0.06,0.65]^{* *}$} & & \\
\hline Metallurgy & $8(26.7)$ & $22(73.3)$ & 0.54 & {$[0.26,1.13]$} & & \\
\hline Mineral Resources & $12(36.4)$ & $21(63.6)$ & 0.84 & {$[0.46,1.55]$} & & \\
\hline Others & $1(3.0)$ & $32(97.0)$ & 0.70 & {$[0.01,0.51]^{* *}$} & & \\
\hline \multicolumn{7}{|l|}{ Level of education } \\
\hline Primary & $5(29.4)$ & $12(70.6)$ & 1 & & & \\
\hline Secondary & $18(21.7)$ & $65(78.3)$ & 0.74 & {$[0.32,1.72]$} & & \\
\hline Tertiary & $24(25.5)$ & $70(74.5)$ & 0.87 & {$[0.38,1.96]$} & & \\
\hline \multicolumn{7}{|l|}{ Sex } \\
\hline Male & $48(25.7)$ & $139(74.3)$ & 1 & & & \\
\hline Female & $1(11.1)$ & $8(88.9)$ & 0.43 & {$[0.07,2.80]$} & & \\
\hline \multicolumn{7}{|l|}{ Experiencein mining } \\
\hline $1-5$ years & $29(20.4)$ & $113(79.6)$ & 1 & & 1 & \\
\hline$>5$ years & $20(37.0)$ & $34(63.0)$ & 1.81 & {$[1.13,2.92]^{*}$} & 1.39 & {$[0.88,2.18]$} \\
\hline
\end{tabular}

${ }^{* * *} p<0.001,{ }^{* *} p<0.01,{ }^{*} p<0.05$. significant association between explanatory variables and reporting WRMSDs

$C l$ confidence interval, $P R$ prevalence ratios, WRMSD work related musculoskeletal disorders

Heavy lifting and/or lowering/shovelling for over $2 \mathrm{~h} /$ day was significantly associated with reporting a WRMSD, which is consistent with other studies [24, 26, 33]. This is evident in low income countries where manual labour is used in physically demanding tasks and in most cases manual handling of heavy loads is almost inherent in the mining industry [34]. Heavy lifting and shovelling for prolonged periods involve risk factors such as highly repetitive motions, forceful exertions, vibration exposures, poor/ awkward posture all of which have been shown to cause WRMSDs [14, 35]. This finding justifies the need for ergonomic training and education about prevention and mitigation of WRMSDs in the mining setting in DR Congo. Such trainings should inform the preventive actions specific for ergonomic risks of the different body parts.

In our study, the psychological factor (job demands) was associated with WRMSDs. Workers with low job demands were less likely to report WRMSDs. The effect of psychosocial factors has been implicated by researchers in the causation of WRMSDs [36]. Studies have suggested an association between high job demands and higher presentation of WRMSD symptoms [37, 38].
Higher demands might cause tense scheduling, panic and consequently expose workers to high risk of WRMS Ds. Therefore, there is a need to optimize job design and ensure better physical and psychosocial demands of work. This can both improve productivity while mitigating incidences of WRMSDs.

The results showed no significant association between age and reporting a WRMSD which is in agreement with previous studies $[39,40]$. Some studies have highlighted that reporting MSDs increases with age [41, 42]. With ageing, people become less able to put stress on muscles without risking injuries and are more susceptible to bones breaking [43]. The small sample size may have limited our power to detect this association. Non significant association between work experience and selfreported WRMSDs has also been reported in other similar studies [24, 44] but contrary to the findings by Egwuonwu et al. [25] who found significantly higher WRMSDs among longer serving workers than those with less years. Whereas this association couldn't be verified, long exposures are known to increase the risk 
Table 5 Multivariable analysis of the ergonomic predictors of work-related musculoskeletal disorders

\begin{tabular}{|c|c|c|c|c|c|c|}
\hline \multirow{2}{*}{$\begin{array}{l}\text { Ergonomic } \\
\text { factors }\end{array}$} & \multicolumn{2}{|c|}{ Self-reported WRMSDs in the past 12 months (\%) } & \multicolumn{2}{|c|}{ Unadjusted Model } & \multicolumn{2}{|c|}{ Adjusted model } \\
\hline & Yes $(n=49)$ & No $(n=147)$ & $P R$ & {$[95 \% \mathrm{Cl}]$} & $P R$ & {$[95 \% \mathrm{Cl}]$} \\
\hline \multicolumn{7}{|l|}{ Age in years } \\
\hline$<30$ & $9(24.3)$ & $28(75.7)$ & 1 & & & 1 \\
\hline $30-34$ & $12(22.2)$ & $42(77.8)$ & 0.91 & {$[0.43,1.95]$} & & $0.94(0.39,2.25)$ \\
\hline $35-39$ & $8(16.7)$ & $40(83.3)$ & 0.69 & {$[0.29,1.61]$} & & $0.78(0.28,2.18)$ \\
\hline$\geq 40$ & $20(35.1)$ & $37(64.9)$ & 1.44 & {$[0.74,2.82]$} & & $2.04(0.96,4.37)$ \\
\hline \multicolumn{7}{|c|}{ Level of education } \\
\hline Primary & $5(29.4)$ & $12(70.6)$ & 1 & & & 1 \\
\hline Secondary & $18(21.7)$ & $65(78.3)$ & 0.74 & {$[0.32,1.72]$} & & $0.39(0.18,0.85) *$ \\
\hline Tertiary & $24(25.5)$ & $70(74.5)$ & 0.87 & {$[0.38,1.96]$} & & $0.81(0.42,1.57)$ \\
\hline \multicolumn{7}{|l|}{ Experience } \\
\hline $1-5$ years & $29(20.4)$ & $113(79.6)$ & 1 & & & 1 \\
\hline$>5$ years & $20(37.0)$ & $34(63.0)$ & 1.81 & {$[1.13,2.92]^{*}$} & & $1.23(0.73,2.07)$ \\
\hline \multicolumn{7}{|c|}{ Duration of the Shifts } \\
\hline$\leq 9 h$ & $2(6.1)$ & $31(93.9)$ & 1 & & 1 & \\
\hline$>9 h$ & $47(28.8)$ & $116(71.2)$ & 4.76 & {$[1.21,18.69]^{*}$} & 3.56 & {$[1.76,16.58]^{*}$} \\
\hline \multicolumn{7}{|c|}{ Heavy/frequent lifting / lowering / shoveling } \\
\hline No exposure & $17(24.6)$ & $52(75.4)$ & 1 & & 1 & \\
\hline Caution & $15(16.3)$ & $77(83.7)$ & 0.66 & {$[0.36,1.23]$} & 0.50 & {$[0.27,1.04]$} \\
\hline Hazard & $17(48.6)$ & $18(51.4)$ & 1.97 & {$[1.15,3.37]^{* *}$} & 1.69 & {$[1.32,3.24] *$} \\
\hline \multicolumn{7}{|c|}{ Awkward postures } \\
\hline No exposure & $9(18.8)$ & $39(81.28)$ & 1 & & 1 & \\
\hline Caution & $15(19.2)$ & $63(80.8)$ & 1.03 & {$[0.49,2.16]$} & 1.38 & {$[0.67,2.86]$} \\
\hline Hazard & $25(35.7)$ & $45(64.3)$ & 1.90 & {$[0.98,3.72]$} & 1.26 & {$[0.63,2.54]$} \\
\hline \multicolumn{7}{|c|}{ High hand force } \\
\hline No exposure & $15(25.9)$ & $43(74.1)$ & 1 & & & \\
\hline Caution & $11(17.5)$ & $52(82.5)$ & 0.68 & {$[0.34,1.35]$} & & \\
\hline Hazard & $23(30.7)$ & $52(69.3)$ & 1.19 & {$[0.68,2.06]$} & & \\
\hline \multicolumn{7}{|c|}{ Highly repetitive work } \\
\hline No exposure & $18(20.9)$ & $68(79.1)$ & 1 & & & \\
\hline Caution & $18(27.3)$ & $48(72.7)$ & 1.30 & {$[0.74,2.31]$} & & \\
\hline Hazard & $13(29.6)$ & $31(70.4)$ & 1.41 & {$[0.76,2.61]$} & & \\
\hline \multicolumn{7}{|l|}{ Vibrating tools } \\
\hline No exposure & $23(20.5)$ & $89(79.5)$ & 1 & & & \\
\hline Caution & $12(24.0)$ & $38(76.0)$ & 1.17 & {$[0.63,2.16]$} & & \\
\hline Hazard & $14(41.2)$ & $20(58.8)$ & 2.01 & {$[1.16,3.45]^{* *}$} & & \\
\hline \multicolumn{7}{|l|}{ Bouncing } \\
\hline No exposure & 21 (19.6) & $86(80.4)$ & 1 & & & \\
\hline Caution & $9(24.3)$ & $28(75.7)$ & 1.24 & {$[0.62,2.46]$} & & \\
\hline Hazard & $19(36.5))$ & $33(63.5)$ & 1.86 & {$[1.10,3.15]^{*}$} & & \\
\hline \multicolumn{7}{|l|}{ Static postures } \\
\hline No exposure & $10(16.1)$ & $52(83.9)$ & 1 & & & \\
\hline Caution & $22(31.0)$ & $49(69.0)$ & 1.92 & {$[0.99,3.74]$} & & \\
\hline Hazard & $17(27.0)$ & $46(73.0)$ & 1.67 & {$[0.83,3.37]$} & & \\
\hline
\end{tabular}


Table 5 Multivariable analysis of the ergonomic predictors of work-related musculoskeletal disorders (Continued)

\begin{tabular}{|c|c|c|c|c|c|c|}
\hline \multirow{2}{*}{$\begin{array}{l}\text { Ergonomic } \\
\text { factors }\end{array}$} & \multicolumn{2}{|c|}{ Self-reported WRMSDs in the past 12 months (\%) } & \multicolumn{2}{|c|}{ Unadjusted Model } & \multicolumn{2}{|c|}{ Adjusted model } \\
\hline & Yes $(n=49)$ & No $(n=147)$ & $P R$ & {$[95 \% \mathrm{Cl}]$} & $P R$ & {$[95 \% \mathrm{Cl}]$} \\
\hline \multicolumn{7}{|c|}{ Pushing and pulling } \\
\hline No exposure & $21(22.3)$ & $73(77.7)$ & 1 & & & \\
\hline Caution & $20(28.2)$ & $51(71.8)$ & 1.26 & {$[0.74,2.14]$} & & \\
\hline Hazard & $8(25.8)$ & $23(74.2)$ & 1.16 & {$[0.57,2.34]$} & & \\
\hline
\end{tabular}

of some disorders of the neck and upper limbs and musculoskeletal disorders in general [45].

\section{Study limitations}

As this study was cross sectional, we can not make causal inferences of the associated factors and WRMS Ds. In addition, musculoskeletal symptoms were self- reported, and thus respondents can give vague responses or exaggerate their MSD complaints. The small sample size may also have limited the strength and significance of some associations. More rigorous designs such as prospective cohorts with sufficiently larger sample sizes may be required to provide more sound research evidence. Additionally, in our study, we did not exclude participants who previously underwent surgery, and overweight

Table 6 Multivariable analysis of the psychosocial predictors of work-related musculoskeletal disorders

\begin{tabular}{|c|c|c|c|c|c|c|}
\hline \multirow{2}{*}{$\begin{array}{l}\text { Psychosocial } \\
\text { factors }\end{array}$} & \multicolumn{2}{|c|}{ Self-reported WRMSDs in the past 12 months (\%) } & \multicolumn{2}{|c|}{ Unadjusted Model } & \multicolumn{2}{|c|}{ Adjusted model } \\
\hline & Yes $(n=49)$ & No $(n=147)$ & $P R$ & {$[95 \% \mathrm{Cl}]$} & $P R$ & {$[95 \% \mathrm{Cl}]$} \\
\hline \multicolumn{7}{|l|}{ Age in years } \\
\hline$<30$ & $9(24.3)$ & $28(75.7)$ & 1 & & & 1 \\
\hline $30-34$ & $12(22.2)$ & $42(77.8)$ & 0.91 & {$[0.43,1.95]$} & & $0.64(0.29,1.42)$ \\
\hline $35-39$ & $8(16.7)$ & $40(83.3)$ & 0.69 & {$[0.29,1.61]$} & & $0.56(0.22,1.44)$ \\
\hline$\geq 40$ & $20(35.1)$ & $37(64.9)$ & 1.44 & {$[0.74,2.82]$} & & $1.04(0.53,2.03)$ \\
\hline \multicolumn{7}{|c|}{ Level of education } \\
\hline Primary & $5(29.4)$ & $12(70.6)$ & 1 & & & \\
\hline Secondary & $18(21.7)$ & $65(78.3)$ & 0.74 & {$[0.32,1.72]$} & & \\
\hline Tertiary & $24(25.5)$ & $70(74.5)$ & 0.87 & {$[0.38,1.96]$} & & \\
\hline \multicolumn{7}{|c|}{ Experience in mining sector } \\
\hline $1-5$ years & $29(20.4)$ & $113(79.6)$ & 1 & & & 1 \\
\hline$>5$ years & $20(37.0)$ & $34(63.0)$ & 1.81 & {$[1.13,2.92]^{*}$} & & $1.52(0.85,2.74)$ \\
\hline \multicolumn{7}{|l|}{ Job demands } \\
\hline High & $17(73.9)$ & $6(26.1)$ & 1 & & 1 & \\
\hline Low & $32(18.5)$ & $141(81.5)$ & 0.25 & {$[0.17,0.37]^{* * *}$} & 0.18 & {$[0.08,0.44]^{*}$} \\
\hline \multicolumn{7}{|l|}{ Job insecurity } \\
\hline High & $20(30.8)$ & $45(69.2)$ & 1 & & & \\
\hline Low & $29(22.1)$ & $102(77.9)$ & 0.72 & {$[0.44,1.17]$} & & \\
\hline \multicolumn{7}{|l|}{ Job control } \\
\hline Yes & $12(38.7)$ & $19(61.3)$ & 1 & & & \\
\hline No & $37(22.4)$ & $128(77.6)$ & 0.58 & {$[0.34,0.98]$} & & \\
\hline \multicolumn{7}{|c|}{ Work relationship } \\
\hline Good & $15(27.3)$ & $40(72.7)$ & 1 & & & \\
\hline Bad & $34(24.1)$ & $107(75.9)$ & 0.88 & {$[0.52,1.49]$} & & \\
\hline \multicolumn{7}{|l|}{ Mental state } \\
\hline Not normal & $7(38.9)$ & $11(61.1)$ & 1 & & & 1 \\
\hline Normal & $42(23.6)$ & $136(76.4)$ & 0.61 & {$[0.32,1.15]$} & & $0.61(0.30,1.23)$ \\
\hline
\end{tabular}


participants and these could inflate prevalence of WRMSDs. Nevertheless, the study adds to the growing body of evidence of the factors associated with WRMS Ds in various work settings.

\section{Conclusions}

The study found that WRMSDs are prevalent amongst workers of Twangiza gold mine. The body part most affected by WRMSDs was the lower back. The predictors of WRMSDs included hazardous exposure to lifting/lowering/shovelling and longer work shifts exceeding $9 \mathrm{~h}$, while low demanding jobs were protective against WRMSDs. To prevent WRMSDs, there is need to train workers on ergonomics, reduce workload (hours per shift) and ensure optimal job design enabling better physical and psychosocial demands at work.

\section{Supplementary Information}

The online version contains supplementary material available at https://doi. org/10.1186/s12891-020-03828-8.

Additional file 1:. Questionnaire (English Version)

\section{Abbreviations}

DRC: Democratic Republic of Congo; MSD: Musculoskeletal disorder; PR: Prevalence ratios; WRMSD: Work related Musculoskeletal disorder

\section{Acknowledgements}

The authors would like to thank all of the study participants of this research.

\section{Authors' contributions}

$\mathrm{AO}, \mathrm{DKS}$, and RKM conceived and designed the study protocol. AO, and STW collected and analysed the data. AO and STW carried out analysis and interpretation of the data. AO and STW drafted the manuscript. AO, STW, DKS and RKM critically revised the manuscript for intellectual content. All authors read and approved the final manuscript. AO, STW, DKS and RKM are guarantors of the paper.

\section{Funding}

This study did not receive any external funding support.

\section{Availability of data and materials}

The data that support the findings of this study are available from the corresponding author, upon reasonable request.

\section{Ethics approval and consent to participate}

Ethical approval to conduct this study was obtained from Makerere University School of Public Health Degrees Research and Ethics Committee. Permission was also obtained from the General Manager of the Mine through written feedback. Informed written consent was sought from all the participants and they were told they could refuse to participate and withdraw from the study at any time. The participants were assured that all responses were completely confidential and personally-identifying data which include the names and ID numbers were not recorded on the datasheets. Participants were informed about the research and the importance of their participation.

\section{Consent for publication \\ Not applicable.}

\section{Competing interests}

The authors declare that there is no conflict of interest regarding the publication of this paper.

\section{Author details}

${ }^{1}$ Department of Public Health, St Mary's Hospital Lacor, Gulu, Uganda. ${ }^{2}$ Department of Disease Control and Environmental Health, Makerere University School of Public Health, Kampala, Uganda.

Received: 10 June 2020 Accepted: 24 November 2020

Published online: 01 December 2020

\section{References}

1. Collins RM, Janse Van Rensburg DC, Patricios JS. Common work-related musculoskeletal strains and injuries. S Afr Fam Pract. 2011;53(3):240-6.

2. Kunda R, Frantz J, Karachi F. Prevalence and ergonomic risk factors of workrelated musculoskeletal injuries amongst underground mine workers in Zambia. J Occup Health. 2013;55(3):211-7.

3. Storheim K, Zwart J. Musculoskeletal disorders and the global burden of disease study. Ann Rheum Dis. 2014;73:949-50.

4. Bevan S. Economic impact of musculoskeletal disorders (MSDs) on work in Europe. Best Pract Res Clin Rheumatol. 2015;29(3):356-73.

5. Corporation B. Operations: Twangiza [internet]. Kinshasa (CD): Banro Corporation; 2018. [July 9, 2018]. Available from: https://banro.com/ operations/twangiza/.

6. Harrison J, Dawson L. Occupational health: meeting the challenges of the next 20 years. Saf Health Work. 2016;7(2):143-9.

7. Belinda D. Musculoskeletal disorders in the south African mining industry [dissertation]. Johannesburg (ZA): University of the Witwatersrand; 2014.

8. Erick PN, Smith DR. The prevalence and risk factors for musculoskeletal disorders among school teachers in Botswana. Occup Med Health Aff. 2014; 2(4):178.

9. Stankevitz K, Schoenfisch A, de Silva V, Tharindra H, Stroo M, Ostbye T. Prevalence and risk factors of musculoskeletal disorders among Sri Lankan rubber tappers. Int J Occup Environ Health. 2016;22(2):91-8.

10. Ekpenyong CE, Inyang UC. Associations between worker characteristics, workplace factors, and work-related musculoskeletal disorders: a crosssectional study of male construction workers in Nigeria. Int J Occup Saf Ergon. 2014;20(3):447-62.

11. Michelo P, Bråtveit M, Moen BE. Occupational injuries and fatalities in copper mining in Zambia. Occup Med (Lond). 2009;59(3):191-4.

12. Wanyonyi NEN, Frantz J. Prevalence of work-related musculoskeletal disorders in Africa: a systematic review. Physiotherapy. 2015;101(1):e1604-5.

13. El-Menyar A, Mekkodathi A, Al-Thani H. Occupational injuries: global and local perspectives. Nepal J Epidemiol. 2016:6(2):560-2.

14. da Costa BR, Vieira ER. Risk factors for work-related musculoskeletal disorders: a systematic review of recent longitudinal studies. Am J Ind Med. 2010;53(3):285-323.

15. Summers K, Jinnett K, Bevan S. Musculoskeletal disorders, workforce health and productivity in the United States. In: The center for workforced health and performance, Lancaster university; 2015. Contract No.: June 30.

16. Kish L. Survey sampling. New York: Wiley; 1965.

17. Daniel WW, Cross CL. Biostatistics: a foundation for analysis in the health sciences: Wiley; 2018.

18. Lwanga SK, Lemeshow S. Sample size determination in health studies: a practical manual. World Health Organ. 1991:1-3. https://apps.who.int/iris/ bitstream/handle/10665/40062/9241544058_\%28p1-p22\%29.pdf? sequence= 1\&isAllowed=y.

19. Bartlett JE, Kotrlik JW, Higgins CC. Organizational research: Determining appropriate sample size in survey research. Inf Technol Learn Perform J. 2001;19(1):43.

20. Kuorinka I, Jonsson B, Kilbom A, Vinterberg $H$, Biering-Sørensen $F$, Andersson $G$, et al. Standardised Nordic questionnaires for the analysis of musculoskeletal symptoms. Appl Ergon. 1987;18(3):233-7.

21. Ohlsson K, Attewell RG, Johnsson B, Ahlm A, Skerfving S. An assessment of neck and upper extremity disorders by questionnaire and clinical examination. Ergonomics. 1994;37(5):891-7.

22. Palmer K, Smith G, Kellingray S, Cooper C. Repeatability and validity of an upper limb and neck discomfort questionnaire: the utility of the standardized Nordic questionnaire. Occup Med (Oxford, England). 1999; 49(3):171-5.

23. Newcombe PJ, Connolly S, Seaman S, Richardson S, Sharp SJ. A two-step method for variable selection in the analysis of a case-cohort study. Int J Epidemiol. 2017;47(2):597-604. 
24. Tawiah AK, Oppong-Yeboah B, Bello Al. Work-related musculoskeletal disorders among workers at gold mine industry in Ghana: prevalence and patterns of occurrence. Br J Med Med Res. 2015;9(8):1-9.

25. Egwuonwu V, Abidemi T, Aiyejunsunle C, Ezeukwu O, Auwal A, Okoye C. A cross-sectional survey of work related musculoskeletal disorders prevalence and associated risk factors among quarry workers in a south eastern Nigerian community. Int J Epidemiol. 2013;11(2):1-5.

26. Punnett $\mathrm{L}$, Wegman DH. Work-related musculoskeletal disorders: the epidemiologic evidence and the debate. J Electromyogr Kinesiol. 2004;14(1): 13-23.

27. Schutte P. Ergonomics in the south African mining industry. J South Afr Inst Min Metall. 2005;105(6):369-72.

28. Sari M, Duzgun HSB, Karpuz C, Selcuk AS. Accident analysis of two Turkish underground coal mines. Saf Sci. 2004;42(8):675-90.

29. Torma-Krajewski J, Steiner L, Lewis P, Gust P, Johnson K. Implementation of an ergonomics process at a US surface coal mine. Int J Ind Ergon. 2007; 37(2):157-67.

30. Lee J-G, Kim GH, Jung SW, Kim SW, Lee J-H, Lee K-J. The association between long working hours and work-related musculoskeletal symptoms of Korean wage workers: data from the fourth Korean working conditions survey (a cross-sectional study). Ann Occup Environ Med. 2018;30:67.

31. Korhan O, Memon AA. Introductory chapter: work-related musculoskeletal disorders. Work-related Musculoskeletal Disorders: IntechOpen; 2019.

32. Dick RB, Lowe BD, Lu M-L, Krieg EF. Further trends in work-related musculoskeletal disorders: a comparison of risk factors for symptoms using quality of work life data from the 2002, 2006, and 2010 general social survey. J Occup Environ Med. 2015;57(8):910-28.

33. Karra VK. Analysis of non-fatal and fatal injury rates for mine operator and contractor employees and the influence of work location. I Saf Res. 2005; 36(5):413-21.

34. Bio F, Sadhra S, Jackson C, Burge P. Low back pain in underground gold miners in Ghana. Ghana medical journal. 2007:41(1):21-5.

35. Antwi-Afari M, Li H, Edwards D, Pärn E, Seo J, Wong A. Biomechanical analysis of risk factors for work-related musculoskeletal disorders during repetitive lifting task in construction workers. Autom Constr. 2017:83:41-7.

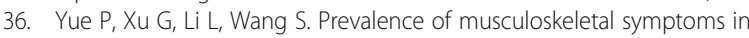
relation to psychosocial factors. Occup Med (Oxford, England). 2014;64(3): 211-6.

37. Dembe $A E$, Erickson JB, Delbos RG, Banks SM. The impact of overtime and long work hours on occupational injuries and illnesses: new evidence from the United States. Occup Environ Med. 2005;62(9):588-97.

38. International Labour Organization (ILO). Workplace Stress, a collective challenge. Geneva: International Labour Office; 2016. Report No.: 978-92-2130642-9.

39. Komljenovic D, Groves WA, Kecojevic VJ. Injuries in US mining operations-a preliminary risk analysis. Saf Sci. 2008:46(5):792-801.

40. Heiden B, Weigl M, Angerer P, Müller A. Association of age and physical job demands with musculoskeletal disorders in nurses. Appl Ergon. 2013;44(4): 652-8.

41. Berberoğlu U, Tokuç B. Work-related musculoskeletal disorders at two textile factories in Edirne, Turkey. Balkan Med J. 2013;30(1):23-7.

42. Okunribido $\mathrm{OO}, \mathrm{Wynn} \mathrm{T}$, Lewis $\mathrm{D}$. Are older workers at greater risk of musculoskeletal disorders in the workplace than young workers? - A literature review. Occup Ergon. 2011;10(1,2):53-68.

43. Ahmad A, Alvi R. Musculoskeletal disorders and risk factors of workers in Indian mining industry: a cross-sectional study. Int J Perceptions Public Health. 2017;1 (4):241-8.

44. Askaripoor T, Kermani A, Jandaghi J, Farivar F. Survey of musculoskeletal disorders and ergonomic risk factors among dentists and providing control measures in Semnan. J Health hyyg. 2013;4(3):241-8.

45. Punnett L. Ergonomic stressors and upper extremity disorders in vehicle manufacturing: cross sectional exposure-response trends. Occup Environ Med. 1998:55(6):414-20.

\section{Publisher's Note}

Springer Nature remains neutral with regard to jurisdictional claims in published maps and institutional affiliations.

Ready to submit your research? Choose BMC and benefit from:

- fast, convenient online submission

- thorough peer review by experienced researchers in your field

- rapid publication on acceptance

- support for research data, including large and complex data types

- gold Open Access which fosters wider collaboration and increased citations

- maximum visibility for your research: over $100 \mathrm{M}$ website views per year

At BMC, research is always in progress.

Learn more biomedcentral.com/submissions 